\title{
CASEIN IN INFANT FEEDING. EXPERIMENTS IN EXACT PERCENTAGES *
}

\author{
HENRY I. BOWDITCH, M.D., AND A. W. BOSWORTH, A.M. \\ BOSTON
}

The proteins of cow's milk have been the source of much interesting discussion and controversy among pediatricians. Theories as to their digestibility are changing almost yearly. Whey proteins advocated by Rotch have given place to the "whole proteins" of Czerny, Keller and Walls (which bring forward the digestibility of skim-milk); while others have heated, peptonized and lately precipitated the proteins in further attempts to improve our knowledge and treatment. Up to the present the proteins of milk formulas have not received the attention we should expect. Protein requirements have painstakingly been estimated and the formulas prescribed, but no one has seriously questioned the accuracy of such mixtures. Several days during the summer of 1912, formulas made according to Finklestein's method were found on examination to contain proteins varying from 2.5 to 4.5 per cent. This instance of error led us to investigate the composition of home modifications and laboratory milk formulas.

\section{METHODS OF ANALYSIS}

1. Total Protein.-Total nitrogen was determined by Folin's modification of Kjeldahl's method. Total nitrogen multiplied by 6.37 gave the total protein.

2. Casein.-Casein was determined by the volumetric method devised by Van Slyke and Bosworth ${ }^{1}$ of the New York Agricultural Experiment Station.

"Its operation in the determination of casein in a sample of milk requires only from twelve to fifteen minutes and the result was reasonably accurate, usually coming within 0.1 to 0.2 per cent. of the correct amount." This method requires the simplest and most inexpensive equipment. It further is eminently practical in the hands of unskilled persons after a minimum of instruction.

3. Albumin.-Albumin when determined was found by subtracting the per cent. of casein from the per cent. of total proteins.

\section{STUDY OF PERCENTAGES OF CASEIN IN LABORATORY MILK FORMULAS}

In Table 1 will be found the results obtained from the examination of twenty mixtures obtained from a food laboratory. These were made from 32 per cent. cream, fat-free milk, whey, ete., from a reliable source. In each case the prescribed formulas are given, while in the last column the

\footnotetext{
* From the Massachusetts Babies Hospital, 106 Chestnut Avenue, Jamaica Plain, Mass.

* Read at the meeting of the American Pediatric Society, Washington, D. C., June, 1913 .

1. Van Slyke and Bosworth: New York Merl. Jour., Sept. 18, 1909.
} 
amounts of variations from these formulas are seen. It will be noticed that in every case the total protein found was less than that called for. No determinations of fats or sugars were made. If as much error occurred with them as was found with the protein, many of the formulas would have been very deficient in caloric value. These errors we at first

TabLE 1.-Percentages of Casein, Etc., in Laboratory Milk Formulas

\begin{tabular}{|c|c|c|c|c|c|c|c|}
\hline \multirow{2}{*}{ Sample } & \multicolumn{3}{|c|}{ Formulae Prescribed } & \multicolumn{2}{|c|}{ Found } & \multirow{2}{*}{\multicolumn{2}{|c|}{ Error }} \\
\hline & Fat & Sugar & Protein & Casein & $\begin{array}{c}\text { Protein } \\
\text { Total }\end{array}$ & & \\
\hline 1 & 4.0 & 7.0 & 1.50 & 1.1 & 1.2 & $(-)$ & 0.3 \\
\hline 2 & 4.0 & 6.0 & 1.60 & 1.3 & 1.4 & $(-)$ & 0.2 \\
\hline $\mathbf{3}$ & 4.0 & 7.0 & 2.50 & 1.5 & 2.1 & $(-)$ & 0.4 \\
\hline 4 & 4.0 & 7.0 & 2.00 & 1.4 & 1.8 & (一) & 0.2 \\
\hline $\mathbf{5}$ & 2.5 & 7.0 & $.50-1.20$ & 1.4 & 1.4 & $i-)$ & 0.3 \\
\hline 6 & 2.25 & 5.0 & $.90-0.25$ & 0.3 & 0.9 & $(-)$ & 0.2 \\
\hline 7 & 1.70 & 7.0 & 0.89 & 0.7 & 0.7 & $(-)$ & 0.1 \\
\hline 8 & 2.75 & 6.0 & 1.25 & 0.9 & 0.8 & $(-)$ & 0.4 \\
\hline 9 & 4.0 & 7.0 & 1.50 & 1.0 & 1.0 & $(-)$ & 0.5 \\
\hline 10 & 3.9 & 6.5 & 2.10 & 1.3 & 1.6 & $(-)$ & 0.5 \\
\hline 11 & 4.0 & 7.0 & 2.00 & 1.4 & 1.6 & $(-)$ & 0.4 \\
\hline 12 & 3.75 & 6.75 & 1.50 & 1.2 & 1.2 & $(-)$ & 0.3 \\
\hline 13 & 3.60 & 6.50 & $.90-0.50$ & 0.7 & 1.0 & $(-)$ & 0.4 \\
\hline 14 & 4.0 & 7.0 & 2.25 & 1.4 & 1.9 & $(-)$ & 0.3 \\
\hline 15 & 4.0 & 7.0 & 2.50 & 1.5 & 2.2 & $(-)$ & 0.3 \\
\hline 16 & 3.75 & 6.75 & $.90-1.00$ & 1.2 & 1.7 & $(-)$ & 0.2 \\
\hline 17 & 4.0 & 6.75 & 1.50 & 1.1 & 1.3 & $(-)$ & 0.2 \\
\hline 18 & 3.25 & 5.50 & 3.25 & 1.7 & 2.7 & $(-)$ & 0.3 \\
\hline 19 & 4.0 & 7.0 & 1.75 & 1.4 & 1.6 & $(-)$ & 0.1 \\
\hline 20 & 2.50 & 5.50 & 0.75 & 0.6 & 0.6 & $(-)$ & 0.1 \\
\hline
\end{tabular}

Table 2.-Analysis of Percentage Cream and Milk

\begin{tabular}{|c|c|c|c|c|c|}
\hline Date & $\begin{array}{l}32 \% \text { Cream } \\
\text { T. P. Cas. Alb. }\end{array}$ & $\begin{array}{l}\text { 16\% Cream } \\
\text { T. P. Cas. Alb. }\end{array}$ & $\begin{array}{l}{ }^{4 \%} \text { Milk } \\
\text { T. P. Cas. Alb. }\end{array}$ & $\begin{array}{l}\text { F. F. Milk } \\
\text { T. P. Cas. Alb. }\end{array}$ & 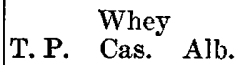 \\
\hline $\begin{array}{ll}\text { April } & 21 \\
\text { April } & 22 \\
\text { April } & 23\end{array}$ & $\begin{array}{l}2.28=1.5(0.78) \\
2.10=1.4(0.70) \\
2.17=1.5(0.67)\end{array}$ & $\begin{array}{l}2.50=1.6(0.90) \\
2.58=1.5(1.0) \\
2.70=1.7(1.0)\end{array}$ & $\begin{array}{l}2.76=2.0(0.76) \\
2.88=2.1(0.78) \\
2.97=2.1(0.87)\end{array}$ & $\begin{array}{l}3.16=2.2(0.96) \\
3.08=2.1(0.98) \\
3.19=2.2(0.99)\end{array}$ & $\begin{array}{l}0.78=0.0(.78) \\
0.87=0.0(.87) \\
0.87=0.0(.87)\end{array}$ \\
\hline
\end{tabular}

put down to irregularities in the milk and cream used in making the mixtures. On examination of these products, however, we found that they were fairly uniform in composition, as is shown by the figures in Table 2. The greatest variations are found with the creams, but the actual error caused by these variations would be very small, as the creams are always diluted with the other ingredients in the mixture. 
STUDY OF PERCENTAGES OF CASEIN IN HOME MODIFIED FORMULAS

Table 3, in contrast with Table 1, gives the results of examination of fifteen home modifications. These were made from 10 per cent. cream and fat-free milk which were furnished by a reliable dairyman. It will be noticed that only six of the fifteen mixtures contained less protein than the formulas called for, while the average error is much less than in the case of the mixture prepared in the food laboratory. We can give only one feasible explanation for the variations and deficient proteins found among the laboratory formulas, i. e., that there is a lack of careful technic on the part of those concerned in making the mixtures correspond more closely to the prescribed formulas.

TABLE 3.-Analysis of Home Modifications

\begin{tabular}{|c|c|c|c|c|c|c|}
\hline \multirow{2}{*}{ Sample } & \multicolumn{3}{|c|}{ Formulae Prescribed } & \multicolumn{2}{|c|}{ Found } & \multirow{2}{*}{ Error } \\
\hline & Fat & Sugar & Protein & Casein & $\begin{array}{c}\text { Total } \\
\text { Protein }\end{array}$ & \\
\hline 1 & 2.0 & 6.0 & 1.00 & 0.85 & 1.05 & ( ) 0.0 \\
\hline 2 & 2.0 & 4.0 & 1.50 & 1.4 & 1.85 & $(+) 0.3$ \\
\hline 3 & 2.5 & 6.5 & 2.75 & 2.0 & 2.8 & $(+) 0.1$ \\
\hline 4 & 1.25 & 6.5 & 1.25 & 1.0 & 1.37 & $(+) \quad 0.1$ \\
\hline 5 & 2.0 & 6.5 & 1.2 & 0.85 & 1.16 & $(-) 0.1$ \\
\hline 6 & 1.75 & 7.0 & 1.5 & 1.2 & 1.5 & $(-) \quad 0.0$ \\
\hline 7 & 2.0 & 6.5 & 1.5 & 1.3 & 1.7 & $(+) \quad 0.2$ \\
\hline 8 & 3.25 & 7.0 & 1.75 & 1.1 & 1.6 & (-) 0.1 \\
\hline 9 & 2.0 & 6.5 & 1.6 & 1.0 & 1.4 & $(-) \quad 0.2$ \\
\hline 10 & 1.25 & 6.5 & 1.2 & 0.8 & 1.1 & $(-) 0.1$ \\
\hline 11 & 2.0 & 6.5 & 1.6 & 1.4 & 1.8 & $(+) 0.2$ \\
\hline 12 & 2.25 & 6.5 & 1.6 & 1.0 & 1.4 & (一) 0.2 \\
\hline 13 & 3.25 & 7.0 & 1.7 & 1.2 & 1.6 & (一) 0.1 \\
\hline 14 & 2.0 & 7.0 & 1.5 & 1.1 & 1.5 & ( ) 0.0 \\
\hline 15 & 2.0 & 3.0 & 2.0 & 1.7 & 2.2 & $(+) \quad 0.2$ \\
\hline
\end{tabular}

\section{POSSIBLE METHODS OF OVERCOMING THIS DEFICTENCY OF PROTEIN}

There are three methods of making up formulas which will give a more exact casein content: (a) Secure cream and skimmed-milk from a reliable dealer and have him furnish proper analysis of the same. From the analysis a mixture of any desired composition can be made with a few simple calculations. This method is recommended for home use under the direction of a physician. (b) Recommended for hospitals and institutions: Secure cream and fat-free milk. Determine the percentage of fat in the cream by the Babcock test. Determine the percentages of casein in the cream and fat-free milk by the volumetric method of Van Slyke and Bosworth.

The percentage of casein multiplied by 1.4 would give the percentage of total protein (or a figure which is close enough to it for all practical 
purposes). By the use of simple calculations, mixtures can be made which will vary from the formula by about 0.1 of protein. (c) This method is in the experimental stage and is not recommended for general use at present. The desired mixture is made by using the necessary amount of cream, whey, etc., and dry powdered casein or paracasein. The percentages of fat and protein in the cream are determined and the whey is assumed to contain 0.9 per cent. protein. (N. B. It is quite important that some whey be used, as it furnishes the inorganic constituents demanded by the growing baby. The proper amount of whey to be used has not been accurately worked out as yet.) The amount of protein necessary to complete the formula is secured by adding in the form of dry powder, casein or paracasein. ${ }^{2}$

\section{EXPERIMENTS WITH DRIED POWDERED PARACASEIN}

One of the preliminary experiments which was carried out is seen in the following. It was undertaken to determine the digestibility of formulas made with dry powdered casein.

TABLE 4.-ANalysis of Form ulas in Author's Experiments

\begin{tabular}{|c|c|c|c|c|c|c|c|c|c|c|}
\hline \multirow{2}{*}{ Experiment } & \multirow{2}{*}{ Date } & \multicolumn{3}{|c|}{ Formula } & \multirow{2}{*}{$\begin{array}{l}\text { Protein in Food } \\
\text { by Analysis }\end{array}$} & \multirow{2}{*}{$\begin{array}{c}\text { Volume } \\
\text { Taken }\end{array}$} & \multicolumn{4}{|c|}{ Nitrogen } \\
\hline & & Fat & Sugar & Prot. & & & $\begin{array}{l}\text { Ingested } \\
\text { gm. }\end{array}$ & $\begin{array}{r}\text { Exc } \\
\mathbf{g}\end{array}$ & ted & $\begin{array}{l}\text { Retained } \\
\text { gm. }\end{array}$ \\
\hline & April & & & & & & & Urine & Feces & \\
\hline 1 & $\begin{array}{l}12 \\
13\end{array}$ & $\begin{array}{l}2 \\
2\end{array}$ & $\begin{array}{l}4 \\
4\end{array}$ & $\begin{array}{l}2 \\
2\end{array}$ & $\begin{array}{l}1.93 \\
1.93\end{array}$ & $\begin{array}{l}1134 \\
1134\end{array}$ & \} 6.9 & 4.90 & .54 & 1.46 \\
\hline\{ & $\begin{array}{l}16 \\
17\end{array}$ & $\begin{array}{l}2 \\
2\end{array}$ & $\begin{array}{l}4 \\
4\end{array}$ & $\begin{array}{l}2 \\
2\end{array}$ & $\begin{array}{l}1.90 \\
1.90\end{array}$ & $\begin{array}{l}1134 \\
1134\end{array}$ & \}$^{6.8}$ & 4.21 & .39 & 2.20 \\
\hline
\end{tabular}

The patient, H. A., was admitted to the hospital Jan. 15, 1913, for observation and feeding. The child was apparently normal, fair physical condition, development and digestion. April 12 the experiment was started. Up to this time the child had been gaining well. His movements were one to two a day, normal, giving no signs of fat, carbohydrate or protein indigestion. His temperature was normal and disposition happy. On April 12 he was placed on the metabolism bed. The food given from April 12 to 16 was made from ten per cent. cream, fat-free milk, lactose and water and had the composition indicated in Table 4 (Experiment 1). Urine and feces were collected for a forty-eight hour period, the feces being marked off by carmin red. The figures obtained are also given as Experiment 1, Table 4. The child took the food well, had no temperature, gained in body weight and remained normal in every respect. On April 16 the food was changed. The percentage composition remained the same, but the materials used were different; cream, whey, lactose, lime-water and dry powdered paracasein. The food was well taken, the child's well being and general

2. Bowditch: Boston Med. and Surg. Jour., May 15, 1913, p. 722. 
condition continued normal, no rise in temperature developed, he gained in weight and his movements were perfectly smooth and digested, but more formed. The urine and feces were collected for a period of forty-eight hours as before and the figures obtained are given as Experiment 2, Table 4.

From the foregoing we can safely say that laboratory formulas are frequently deficient in protein; that home modified mixtures compare far more favorably on this point. That it does not seem to be the fault of the constituents which go to make these mixtures, but rather the care of those who put up such formulas.

We feel that we have proved that formulas with exact percentages of protein can be obtained by determining the percentage of casein in the creams and milks used, and further, that powdered dry casein and paracasein can be used in making up shortage of protein in place of fat-free or skim-milk. We will also show in a later publication that this powdered dry casein or paracasein is very easily digested, and is capable of furnishing all the protein requirements of the growing baby.

This procedure of accurate determination of protein may or may not be of service. It remains to be seen how far it can be used. It is certainly not necessary to go into such details in general, but special cases may bear more fruit when we consider the possible errors and the resultant underfeeding of protein as we have illustrated above. This is the beginning of a series of experiments to be continued along similar lines.

We wish to express our thanks to Dr. Helen Dudley of Brooklyn, New York, for her interest and time. 